\title{
INTERPRETASI DATA RESISTIVITAS UNTUK MENGIDENTIFIKASI MUNCULNYA LONGSOR SUSULAN DI BLOK V WAYAME AMBON
}

\section{Resistivity Data Interpretation To Identify The Appearance Of Subsequence Landslide In Block V Wayame Ambon}

\author{
Sisca M. Sapulete ${ }^{1 *}$, Matheus Souisa ${ }^{2}$, Sitti Jubaedah ${ }^{3}$ \\ ${ }^{1.2,3}$ Laboratorium Geosains Jurusan Fisika, Fakultas MIPA Universitas Pattimura \\ ${ }^{1.2}$ Laboratorium Mitigasi Bencana Jurusan Fisika, Fakultas MIPA Universitas Pattimura \\ ${ }^{1.2}$ Laboratorium Gerakan Tanah Jurusan Fisika, Fakultas MIPA Universitas Pattimura \\ Jln. Ir. M. Putuhena, Kampus Unpatti, Poka, Ambon, Indonesia \\ e-mail:1* ${ }^{*}$ sisca_sapulete@yahoo.com; ${ }^{2}$ thos.phys@gmail.com; ${ }^{3}$ sittijubaedah@gmail.com
}

Corresponding author*

\begin{abstract}
Abstrak
Telah dilakukan penelitian untuk interpretasi bidang gelincir longsoran pada daerah bekas longsor di Blok V Wayame Ambon menggunakan metode geolistrik resisivitas konfigurasi WennerSchlumberger. Tujuan penelitian untuk menduga struktur lapisan batuan bawah permukaan dan mengidentifikasi sebaran bidang gelincir berdasarkan penampang resistivitas batuan. Hasil pemodelan resistivitas batuan teridentifikasi adanya zona bidang gelincir pada kedua lintasan pengukuran, dimana pada Lintasan-1 diduga memiliki dua bidang gelincir ditemukan pada kedalaman $2.0 \mathrm{~m}$ terletak pada jarak $6.0 \mathrm{~m}$ dan $38.0 \mathrm{~m}$, sedangkan pada Lintasan-2 diduga mempunyai satu bidang gelincir ditemukan pada kedalaman $2.5 \mathrm{~m}$ terletak pada jarak $28.0 \mathrm{~m}$. Zona bidang gelincir yang merupakan bidang rawan longsor terletak pada kelompok resistivitas menengah $(30-70 \Omega$.m) dengan jenis pasir atau pasir lempungan yang menindih kelompok resistivitas tinggi (> $70 \Omega . \mathrm{m}$ ) yang berupa batu lempung keras (bedrock). Zona yang rawan longsor dapat berpotensi munculnya longsor susulan dengan memungkinkan potensi sebaran longsor tetap pada lokasi semula apabila terjadi gangguan-gangguan pada lereng dan berpeluang bergeser ke arah atas lereng.
\end{abstract}

Kata Kunci: metode geolistrik, penampang resistivitas, longsor, bidang gelincir

\begin{abstract}
Research of the Block V Wayame Ambon slide planes has been carried out using the geoelectric resissivity method of the Wenner-Schlumberger configuration. The purpose of the study was to estimate the structure of the subsurface rock layer and identify the distribution of slide plane based on the cross section of rock resistivity. The rock resistivity modeling results show the existence of a slip zone on both measurement trajectories. On the Line-1 it was assumed that two slide planes found at a depth of $2.0 \mathrm{~m}$ located at a distance of $6.0 \mathrm{~m}$ and $38.0 \mathrm{~m}$, while on the Line-2 the slide planes are in $2.5 \mathrm{~m}$ depth is located at a distance of $28.0 \mathrm{~m}$. The slip zone which is a landslide-prone area lies in the intermediate resistivity group (30-70 $\Omega . m$ ) with the type of sand or clay sand which overlaps the high resistivity group (> $70 \Omega . m$ ) in the form of a hard claystone (bedrock). Landslide-prone zones can have the potential for a subsequent landslide to occur by allowing the potential spread of landslides to remain at their original location in the event of disturbances on the slopes and the opportunity to shift towards the top of the slope.
\end{abstract}

Keywords: Geoelectric method, resistivity cross section, landslide, slide plane 


\section{PENDAHULUAN}

Salah satu wilayah yang memiliki kawasan bencana geologi adalah Kecamatan Teluk Ambon, Kota Ambon. Berdasarkan peta kerentanan gerakan tanah Kota Ambon [5], Kecamatan Teluk Ambon termasuk dalam potensi gerakan tanah antara menengah hingga tinggi karena dilalui oleh sesar Baguala-Banda. Sesar Baguala-Banda merupakan sesar yang kurang aktif dan sewaktu-waktu bisa aktif apabila terjadi pergerakan lempeng tektonik dengan skala sedang hingga tinggi sehingga dapat menyebabkan retakan tanah, dan sebagainya. Disamping itu, Kecamatan Teluk Ambon termasuk bagian dari Pulau Ambon merupakan pulau-pulau busur vulkanis dan berada dalam wilayah kepulauan pulau-pulau kecil yang berhubungan dengan zona penunjaman sehingga mempunyai tingkat kerentanan tinggi terhadap berbagai bencana alam setiap tahun, seperti erosi dan tanah longsor pada kondisi kelerengan tertentu [6]. Bencana gerakan tanah (longsor) yang terjadi di Blok V Desa Wayame Kecamatan Teluk Ambon, mengakibatkan korban jiwa dan kerusakan rumah penduduk dan alterasi terhadap morfologi lahan.

Menyadari kondisi Blok.V Desa Wayame yang rawan terhadap bencana geologi tersebut, maka seyogyanya setiap kegiatan pembangunan fisik di wilayah ini perlu dilakukan perencanaan penataan ruang yang berbasis bencana. Infrastruktur yang memiliki nilai strategis dan nila hidup bagi masyarakat seperti penyediaan rumah tempat hunian oleh pengembang yang dipetakan dalam sistem blok seharusnya ditempatkan pada ruang yang aman dari bahaya bencana. Akibat penggunaan ruang Desa Wayame yang cenderung semakin intensif tersebut, kondisi fisik kawasan terbangun menjadi semakin rentan terhadap bencana gerakan tanah (longsor). Longsor terjadi karena kontak antara batuan yang kedap air dengan batuan yang tidak kedap air sebagai bidang gelincir. Sebagai langkah pencegahan munculnya longsor susulan, maka dilakukan pemetaan geologi bawah permukaan menggunakan metode geofisika resistivitas konfigurasi Wenner-Schlumberger untuk mengidentifikasi sebaran bidang gelincir berdasarkan model penampang resistivitas batuan.

\section{METODE PENELITIAN}

Perombakan material debris pembentuk lereng berupa butiran halus maupun kasar berbentuk tidak beraturan, bergerak menggelinding mengikuti lereng atau bergerak ke arah bawah (downward) dan sampai di kaki lereng material longsor mengendap. Proses pergerakan ini dikenal sebagai gerakan tanah (mass movement) [2]. Material pembentuk lereng tersebut dapat berupa massa batuan induk, lapisan tanah, timbunan buatan manusia atau kombinasi berbagai jenis material tersebut [10]. Gerakan tanah adalah proses perpindahan massa tanah atau batuan dengan arah tegak, mendatar atau miring terhadap kedudukan semula karena pengaruh air, gravitasi, dan beban luar [4],[5]. Gerakan tanah atau gerakan gelincir (sliding movement) menurut Cruden dalam [3] adalah mempunyai kesamaan. Pergerakan tanah membawa material longsor dengan kecepatan tinggi menyebabkan kerusakan infrastruktur dan lingkungan, korban jiwa dan kerugian harta benda yang cukup besar.

Penyebab utama terjadinya longsor di daerah penelitian diperkirakan antara lain terdapat lereng yang terjal dan tanpa penahan, adanya bidang lemah antara batuan segar yang kedap air dengan tanah pelapukan yang lebih poros, yang berpotensi menjadi bidang gelincir, tanah penyusun lereng yang jenuh air akibat terendam air sebelum longsoran terjadi, berada di jalur patahan dan adanya alih fungsi lahan yang tidak tidak terkontrol.

\subsection{Motode Geolistrik Resistivitas}

Metode resistivitas adalah salah satu dari kelompok metode geolistrik yang digunakan untuk mempelajari keadaan bawah permukaan dengan cara mempelajari sifat aliran listrik di dalam batuan di bawah permukaan bumi [12]. Metode resistivitas digunakan untuk survei mineral batuan, gerakan tanah (longsor), intruisi air laut, limbah cair atau padat, panas bumi, situs geologi dan lain sebagainya [1]. Metode resistivitas umumnya digunakan untuk eksplorasi dangkal, sekitar $300-500 \mathrm{~m}$. Prinsip dalam metode ini yaitu arus listrik diinjeksikan ke alam bumi melalui dua elektroda arus, sedangkan beda potensial yang terjadi diukur melalui dua elektroda potensial.

Pada pengukuran geolistrik yang sebenarnya medium tidak homogen dengan distribusi resistivitas sembarang. Pada kenyataannya, bumi merupakan medium berlapis dengan masing-masing lapisan mempunyai nilai resistivitas yang berbeda [1], [4], [7]. Resistivitas semu ini dirumuskan sebagai: 


$$
\rho_{a}=K \frac{\Delta V}{I}
$$

Untuk menghitung resistivitas semu, diperlukan suatu bilangan faktor geometri $(K)$ yang tergantung pada jenis konfigurasi, jarak $\mathrm{AB} / 2$ dan $\mathrm{MN} / 2$ dan untuk menentukan kedalaman maka jarak antara elektroda AM dan NB ditingkatkan menjadi $2 a$ dan pengukuran diulangi untuk $n$ yang sama sampai pada elektroda terakhir, kemudian jarak antara elektroda AM dan NB ditingkatkan menjadi $3 a$, dan seterusnya [4]. Pada Gambar 1, diperlihatkan kedudukan setiap elektroda berdampingan antara satu dengan yang lainnya di mana jarak elektroda potensial (MN) diatur sekecil-kecilnya sehingga secara teoritis konstan tetapi ketika jarak $\mathrm{AB}$ sudah relatif besar maka jarak $\mathrm{MN}$ hendaknya tidak lebih besar dari 1/5 jarak $\mathrm{AB}$.

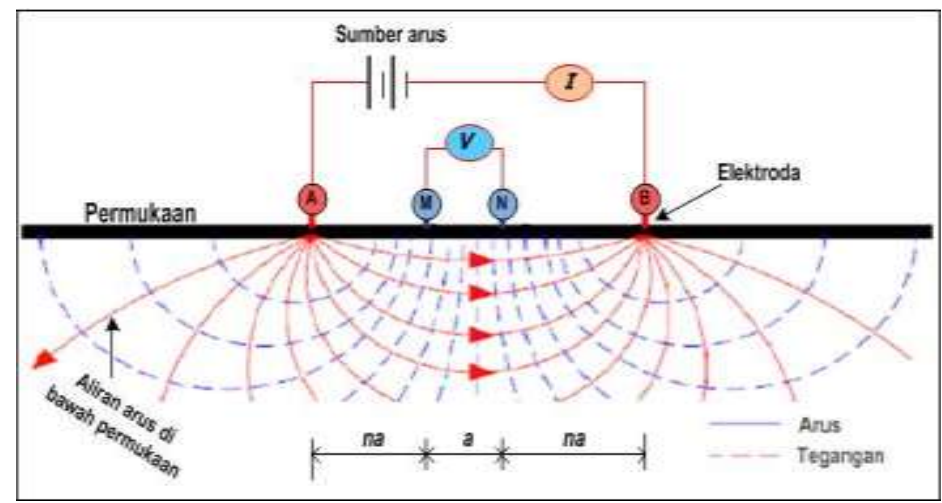

Gambar 1. Letak Posisi Elektroda Konfigurasi Wenner-Schlumberger ([8],[9],[10])

Bertolak dari Gambar 1, diperoleh faktor geometri konfigurasi Wenner-Schlumberger [14] dari [13] diperoleh $K=\operatorname{\pi an}(n+1)$ sehingga menghasilkan persamaan resistivitas batuan dengan konfigurasi Wenner-Schlumberger $[11,12,1]$ sebagai berikut:

$$
\rho_{a}=\frac{\Delta V}{I} K \equiv R[\operatorname{\pi an}(n+1)]
$$

dengan $\rho_{\mathrm{a}}=$ resistivitas semu $(\Omega . \mathrm{m}), \Delta V=$ beda potensial (volt), $I=$ arus listrik (ampere), $K=$ faktor geometri (meter), $R=$ hambatan listrik $(\Omega), n=$ lapisan tanah dan $a=$ jarak (spasi) antar elektroda arus dan potensial (meter).

\subsection{Daerah Penelitian}

Daerah survei pengambilan data resistivitas berada pada daerah bekas longsor di Blok V Desa Wayame Kecamatan Teluk Ambon, Kota Ambon yang terletak pada koordinat $3^{\circ} 39^{\prime} 34.39^{\prime \prime}$ LS dan $128^{\circ} 10^{\prime} 1.77 \mathrm{BT}^{\prime \prime}$ seperti diperlihatkan dalam Gambar 2. Pada umumnya, tatanan stratigrafi daerah penelitian tersusun atas jenis dan distribusi batuan gunungapi Ambon yang paling dominan, batuan permukaan berupa batuan alluvium, dan batuan beku berupa batuan granit Ambon [15]. Dari segi tatanan fisiografi, dimana morfologi tersusun atas satuan perbukitan dataran rendah sampai perbukitan bergelombang sedang kemiringan di atas $40^{\circ}$ dan elevasi mencapai 76 meter di atas permukaan laut (m.dpl). 


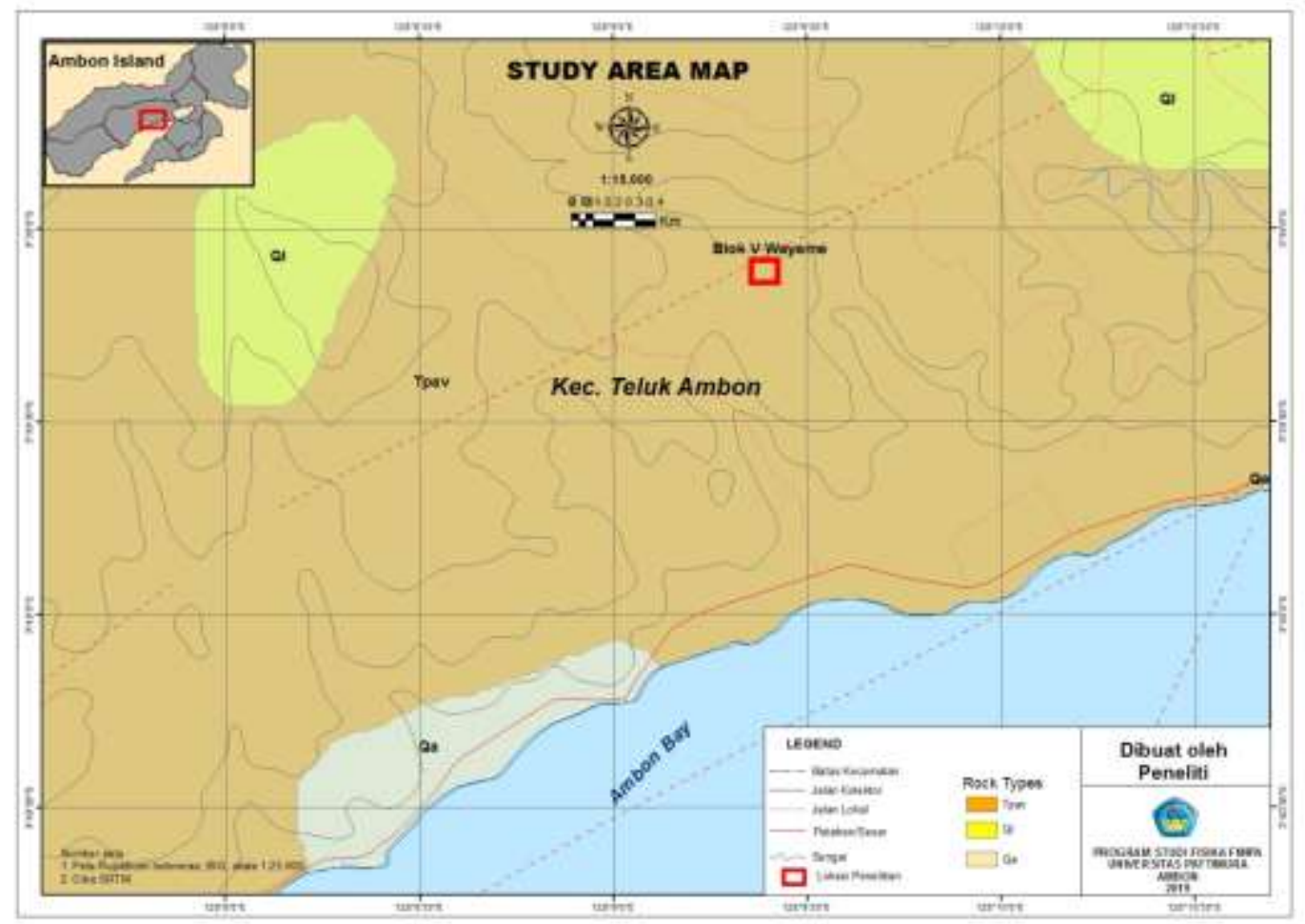

Gambar 2. Peta Geologi Daerah Penelitian (Diolah Kembali Dari [5])

\subsection{Akuisisi Data Resistivitas}

Sebelum melakukan akuisisi data lapangan dengan instrumen resistivity meter, terlebih dahulu dilakukan test peralatan yang digunakan di lapangan. Mempersiapkan stacking chart seperti diperlihatkan dalam Gambar 3 sesuai dengan luas daerah dan kedalaman yang diinginkan pada daerah yang sudah di jejaki sebelumnya. Setelah lintasan dan titik pengamatan ditentukan di daerah penelitian, maka dilakukan akuisisi data resistivitas dengan menggunakan konfigurasi Wenner-Schlumberger. Investigasi daerah survei memiliki luas daerah bekas longsor diperkirakan $(60 \times 60) \mathrm{m}^{2}$ dibagi menjadi dua lintasan masing-masing panjang $50 \mathrm{~m}$ pada arah Timur Laut-Barat Daya dan arah Timur-Barat dengan spasi elektroda $2 \mathrm{~m}$.

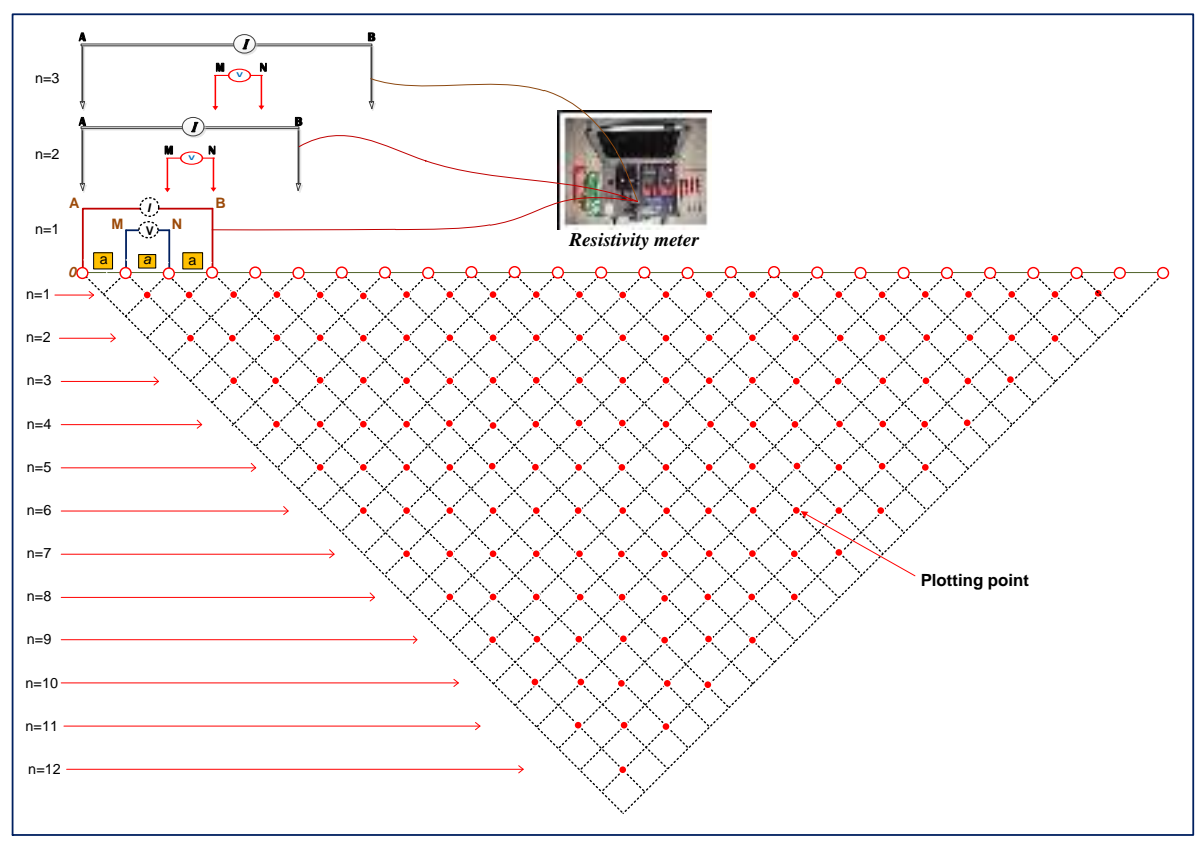

Gambar 3. Stacking Chart Geolistrik Resistivitas (Diolah Kembali Dari [5]) 
Akuisisi data lapangan dimulai dengan tracking koordinat daerah penelitian dan pengambilan titik koordinat lintasan geolistrik selanjutnya dilakukan pengukuran resistivitas pada lintasan geolistrik menggunakan konfigurasi Wenner-Schlumberger. Data pengukuran lapangan berupa data arus $(I)$ dan beda potensial $(\Delta V)$. Pola lintasan ukur dibuat berdasarkan informasi geologi seperti munculnya singkapan urat atau zona-zona alterasi.

Tahapan pengolahan data dilakukan berdasarkan hasil akuisisi data resistivitas seperti data arus $(I)$ dan tegangan $(\Delta V)$. Data ini diolah dengan komputer untuk menghitung nilai resistivitas semu $\left(\rho_{a}\right)$ sebagai data yang belum terkoreksi. Hasil pengolahan selanjutnya mengoreksi nilai $\rho_{a}$ dengan software Res2-Dinv untuk memperoleh pseudosection. Selanjutnya dilakukan proses inversi dalam melakukan pemodelan untuk mencari parameter model bawah permukaan. Proses ini dilakukan sampai diperoleh respon model inversi yang optimal dilihat dari nilai RMS (Root Mean Square) yang relatif kecil. Nilai resistivitas sebenarnya (true resistivity) akan didapatkan setelah melakukan proses inversi dengan menggunakan software Res2Dinv untuk menghasilkan penampang 2-D resistivitas batuan.

\section{HASIL DAN PEMBAHASAN}

\subsection{Topografi daerah penelitian}

Setelah akuisisi data koordinat pada daerah bekas longsor menggunakan GPS, dibuat peta topografi daerah penelitian yang disertai dengan lintasan pengambilan data resistivitas (Gambar 4). Secara geografis posisi daerah penelitian terletak pada koordinat $3^{0} 39^{\prime} 34.39^{\prime \prime} \mathrm{LS}$ dan $128^{0} 10^{\prime} 1.77^{\prime \prime} \mathrm{BT}$ dengan ketinggian 44.0 - 76.0 m.dpl. Pada Gambar 4, kontur berwarna biru pekat menunjukkan daerah yang mempunyai dataran sangat rendah. Kontur warna ungu menunjukkan dataran yang tinggi. Titik B merupakan daerah yang datarannya paling tinggi dibandingkan dengan dataran disekitarnya. Titik $\mathrm{C}$ memperlihatkan dataran yang sangat rendah, karena di dataran ini terdapat pemukiman masyarakat. Daerah di titik D merupakan bekas longsor sehingga daerah ini dijadikan sebagai daerah pengukuran geolistrik resistivitas. Daerah di sebelah Timur Laut titik B menunjukkan arah Lintasan-1 (Line-1) dan lintasan yang memotong lintasan-1 adalah Lintasan-2 (Line-2) terletak dari arah Timur-Barat, dimana pada arah ke Timur merupakan tebing yang sangat terjal yang masih diselimuti dengan beragam vegetasi.

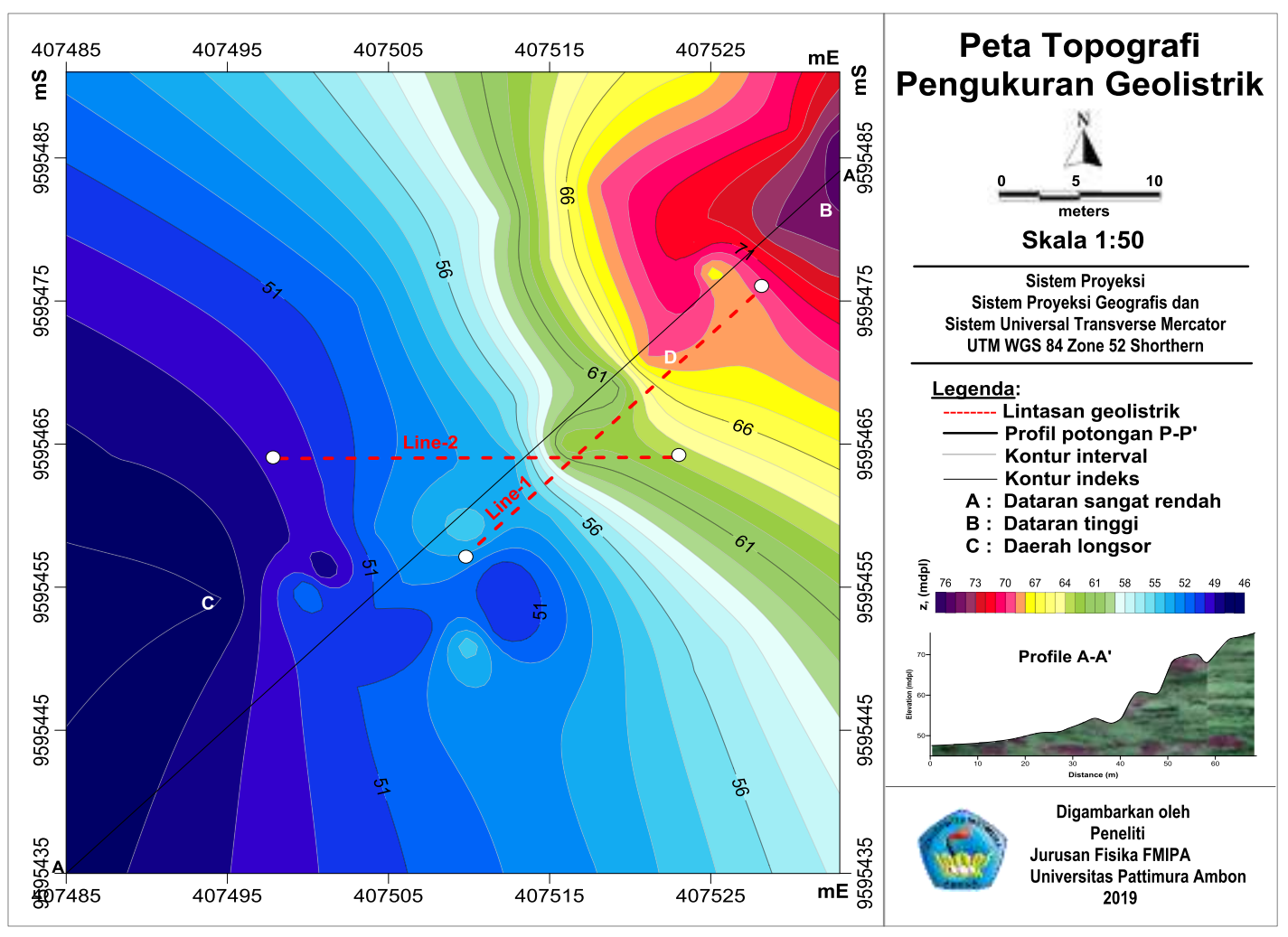

Gambar 4. Peta Topografi Daerah Penelitian 


\subsection{Pemodelan Resistivitas 2-D}

Pengukuran resistivitas lapangan dilakukan dengan metode geolistrik resistivitas konfigurasi Wenner-Schlumberger secara mapping dan sounding. Akuisisi data resistivitas dilakukan pada dua lintasan pengukuran yang berbeda, dimana panjang masing-masing lintasan adalah $50 \mathrm{~m}$. Pengukuran dilakukan hanya pada dua lintasan karena daerah bekas longsor sangat curam dan sempit sehingga tidak mungkin mengambil lintasan yang lebih banyak. Adapun kedua lintasan pengukuran diuraikan sebagai berikut:

1. Akuisisi data resistivitas pada Lintasan-1 membentang dari arah Timur Laut - Barat Daya dengan azimuth $3^{\circ} 39^{\prime} 34.68^{\prime \prime} \mathrm{LS}$ - 128 $10^{\prime} 1.67^{\prime \prime} \mathrm{BT}$ dan $3^{\circ} 39^{\prime} 33.87^{\prime \prime} \mathrm{LS}$ - $128^{0} 10^{\prime} 2.48^{\prime \prime} \mathrm{BT}$ berada pada ketinggian 76.0 m.dpl.

2. Akuisisi data resistivitas pada Lintasan-2 membentang dari arah Barat - Timur dengan azimuth $3^{0} 39^{\prime} 34.26^{\prime \prime} \mathrm{LS}-128^{0} 10^{\prime} 1.25^{\prime \prime} \mathrm{BT}$ dan $3^{0} 39^{\prime} 34.65^{\prime \prime} \mathrm{LS}-128^{0} 10^{\prime} 2.68^{\prime \prime} \mathrm{BT}$ berada pada ketinggian 61.0 m.dpl.

\subsubsection{Lintasan-1 (survei geolistrik di Blok V Wayame)}

Hasil akuisisi data resistivitas pada Lintasan-1, diperoleh 128 datum point dengan panjang lintasan adalah $50.0 \mathrm{~m}$ dan jarak tiap elektroda $2.0 \mathrm{~m}$. Hasil akuisisi data digunakan untuk menghitung nilai resistivitas semu $\left(\rho_{\mathrm{a}}\right)$ dan tahapan selanjutnya diolah menggunakan software Res2-Dinv untuk mendapatkan nilai resistivitas sebenarnya. Perolehan model penampang resistivitas sebenarnya (true resistivity) hasil inversi dimodelkan ulang dengan memasukan data topografi pada tiap jarak elektroda menggunakan jenis jarak kontur berupa interval kontur logaritmik (logarithmic contour intervals). Hasil pemodelan ini diperlihatkan dalam Gambar 5, terdiri dari dua bagian penampang yang masing-masing memperlihatkan citra anomali resistivitas tanpa koreksi topografi (gambar bagian atas), dan citra anomali resistivitas dengan koreksi topografi (gambar bagian bawah).

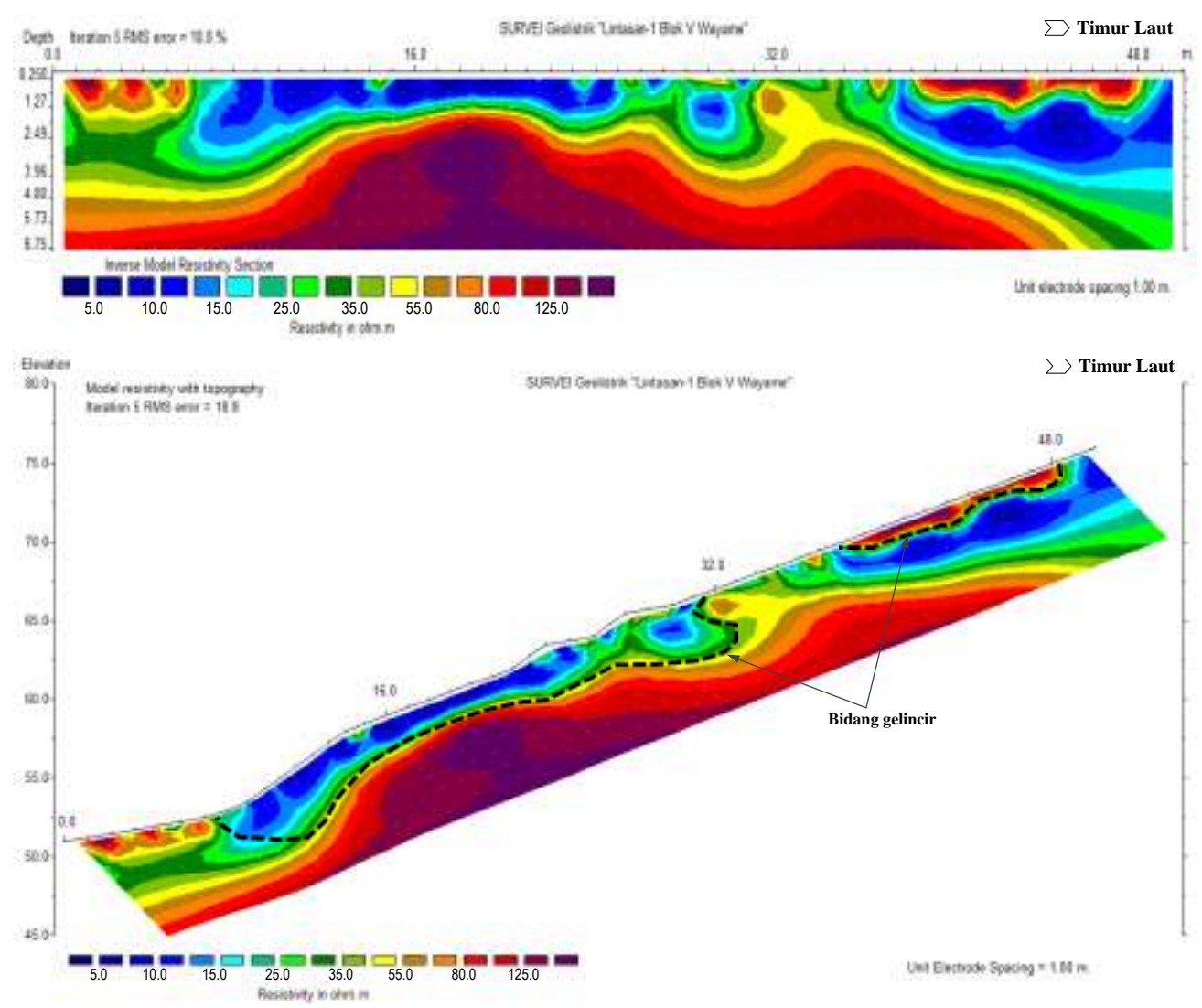

Gambar 5. Penampang Resistivitas 2-D pada Lintasan-1

Berdasarkan hasil pengolahan data true resistivity didapatkan pola perlapisan atau beberapa susunan lapisan batuan yang diinterpretasi adanya dua lapisan bidang gelincir yaitu pada zona jenuh dan zona tak jenuh. Lapisan bidang gelincir sebagai objek penelitian memiliki nilai resistivitas yang relatif rendah berhimpitan dengan lapisan overburden dan bedrock dengan nilai resistivitas tinggi [1, 14]. Interpretasi 
rincian dari hasil perhitungan dan pengolahan data, secara umum dari tiap datum point pada penampang

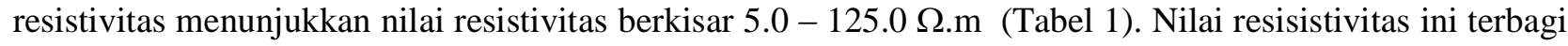
atas tiga zona resistivitas sebagai berikut:

1. Zona resistivitas rendah dengan nilai resistivitas < 25.0 S.m diduga sebagai tanah, lempung dan lempung pasiran, umumnya bersifat lepas dan lembab berwarna coklat hingga coklat-jingga. Material ini umumnya bersifat lepas/lapuk dan cukup berpori sehingga dapat meloloskan air dengan tingkat rendah.

2. Zona resistivitas menengah dengan nilai resistivitas 25.0 - 55.0 $\Omega . m$ diduga sebagai pasir, pasir lempungan berbutir halus hingga kasar, lempungan dan kerikilan. Batuan ini terdapat pada kedalaman dan ketebalan bervariasi. Material ini umumnya bersifat lepas/lapuk dan cukup berpori/berongga sehingga dapat meloloskan air dengan tingkat tinggi.

3. Zona resistivitas tinggi dengan nilai resistivitas $>55.0 \Omega$.m diduga sebagai batu lempung pasiran berbutir halus hingga sedang dan batulempung yang kompak dan keras. Batuan ini terdapat pada kedalaman dan ketebalan bervariasi. Material ini umumnya bersifat kompak. Zona batuan ini umumnya bertindak sebagai batuan dasar (bedrock) dan batuan penutup (overburden) yang dijumpai hampir di seluruh daerah survei.

Tabel 1. Interpretasi litologi berdasarkan resistivitas batuan pada Lintasan-1

\begin{tabular}{|c|c|c|c|c|}
\hline $\begin{array}{c}\text { Resistivitas } \\
\text { sebenarnya } \rho,(\Omega . \mathrm{m})\end{array}$ & Warna & $\begin{array}{c}\text { Zona } \\
\text { resistivitas }\end{array}$ & Kedalaman, (m) & Interpretasi Litologi \\
\hline$<25.0$ & & & $\begin{array}{c}0.25-1.35 \text { dan } \\
1.35-\sim\end{array}$ & $\begin{array}{l}\text { Lapisan tanah, lempung, } \\
\text { lempung pasiran }\end{array}$ \\
\hline $25.0-55.0$ & & Menengah & $0.25-\sim$ & Pasir, pasir lempungan \\
\hline$>55.0$ & & Tinggi & $\begin{array}{c}0.25-1.35 \text { dan } \\
1.35-\sim\end{array}$ & $\begin{array}{l}\text { Tufa-lempung pasiran dan } \\
\text { batuan lempung kompak }\end{array}$ \\
\hline
\end{tabular}

Pada Lintasan-1 (Gambar 5) diduga terdapat dua bidang gelincir masing-masing panjang $\pm 26.0 \mathrm{~m}$ dari posisi $x=6.0 \mathrm{~m}$ pada kedalaman $2.0 \mathrm{~m}$ dari permukaan tanah, dan panjang $\pm 10.0 \mathrm{~m}$ dari posisi $x=38.0 \mathrm{~m}$ dengan kedalaman $2.0 \mathrm{~m}$ dari permukaan tanah. Fitur anomali resistivitas sebaran longsor yang terjadi di zona ini pada arah vertikal cukup dangkal hanya mencapai kedalaman $2.0 \mathrm{~m}$. Dari anomali resisitivitas (Gambar 5), dimungkinkan adanya bidang gelincir, karena terdapat kontras antara lapisan batuan dengan resistivitas rendah, menengah dan tinggi. Lapisan batuan dengan bagian resistivitas rendah berupa batuan lempung yang bersifat lepas dan lembab dan lapisan batuan dengan resistivitas menengah yang memiliki batuan lempung berbutir halus hingga kasar dan cukup berpori serta berongga sehingga dapat meloloskan air karena pada lapisan ini telah jenuh air sehingga mempunyai beban yang lebih berat. Sedangkan lapisan batuan dengan resistivitas tinggi adalah batuan dasar (bedrock) tak lapuk, sehingga apabila ada air yang masuk pada daerah ini, air tersebut akan tertahan di lapisan ini, sehingga lapisan tersebut akan menjadi licin dan mudah tergelincir. Akibat licinnya lapisan tersebut, maka sangat memungkinkan munculnya longsor susulan dan dapat dikatakan bahwa daerah penelitian merupakan daerah yang rawan longsor.

Berdasarkan hasil pemodelan resisitivitas pada Gambar 5, memperlihatkan model resistivitas yang sebenarnya dengan topografi, dimana proses pengolahan model penampang 2-D memungkinkan adanya beberapa kesalahan yaitu kesalahan pemotongan eksekusi nilai resitivitas dan kesalahan topografi. Dari hasil running program dengan menggunakan model inversi berdasarkan jumlah total datum points pada Lintasan-1 adalah 128 dengan cutoff error dari $150 \%$ menghasilkan jumlah kesalahan maksimum $59.0 \%$, seperti diperlihatkan dalam Gambar 6. Sedangkan kesalahan akar rataan kuadrat (Root Mean Square) selama proses iterasi untuk mendapatkan resistivitas sebenarnya adalah sebesar $18.8 \%$. Kesalahan ini masih dalam taraf yang dapat diterima sebagai hasil proses inversi yang baik sesuai dengan kondisi lapangan. 


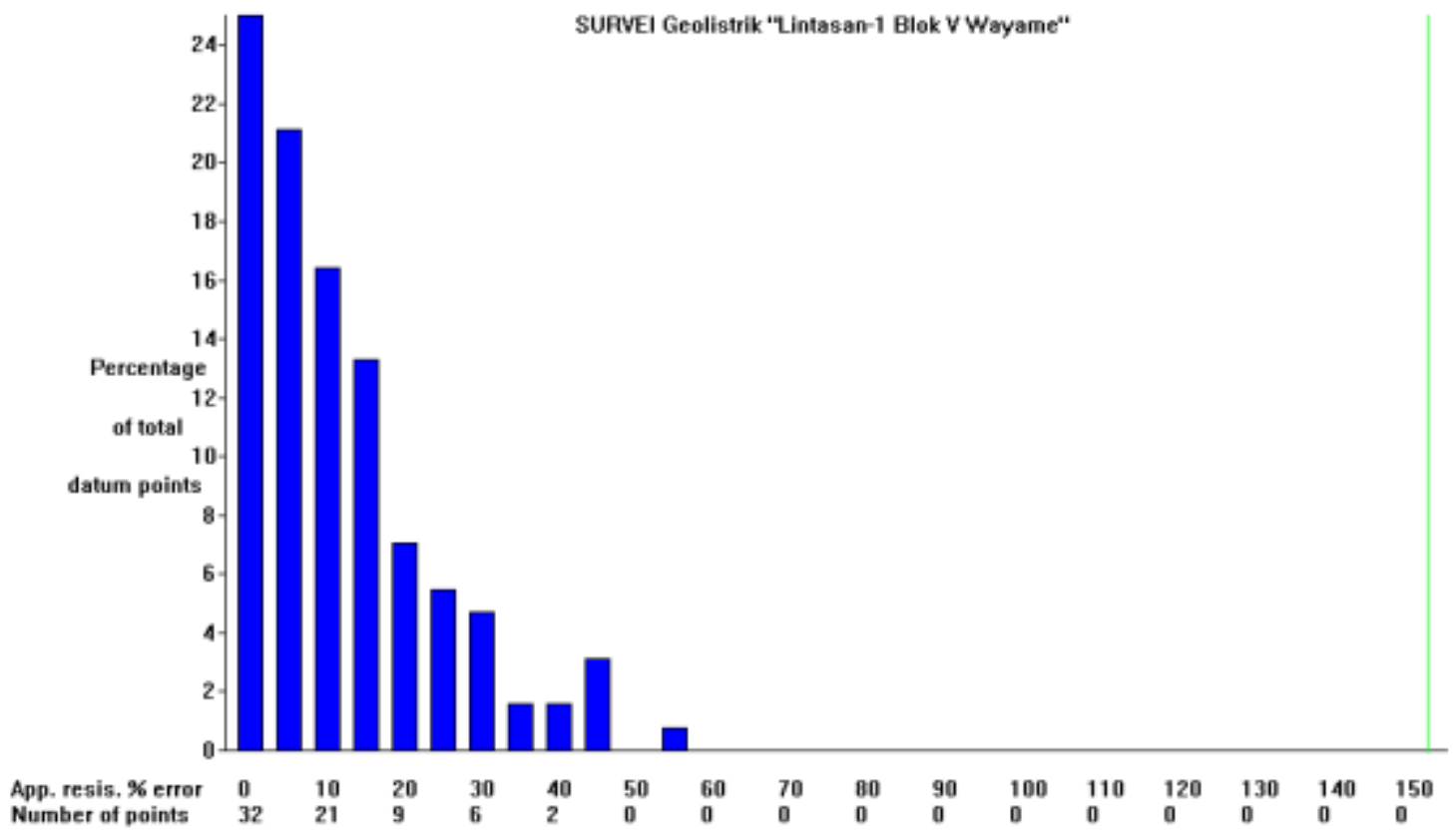

Gambar 6. Statistik Kesalahan Pengolahan Data Pada Lintasan-1

\subsubsection{Lintasan-2 (Survei geolistrik di Blok V Wayame)}

Hasil pengukuran pada Lintasan-2 diperoleh 128 datum point dengan jarak setiap elektroda $2 \mathrm{~m}$ dan panjang lintasan adalah $50 \mathrm{~m}$ yang berada pada ketinggian $76 \mathrm{~m}$. Selanjutnya dihitung nilai resistivitas semu $\left(\rho_{\mathrm{a}}\right)$ dan tahapan berikut diolah menggunakan software Res2-Dinv untuk mendapatkan nilai resistivitas sebenarnya. Hasil pemodelan ini diperlihatkan dalam Gambar 7. Pada Gambar 7, terdiri atas dua bagian yang masing-masing memperlihatkan anomali resistivitas tanpa koreksi topografi (gambar bagian atas), dan anomali resistivitas dengan koreksi topografi (gambar bagian bawah).
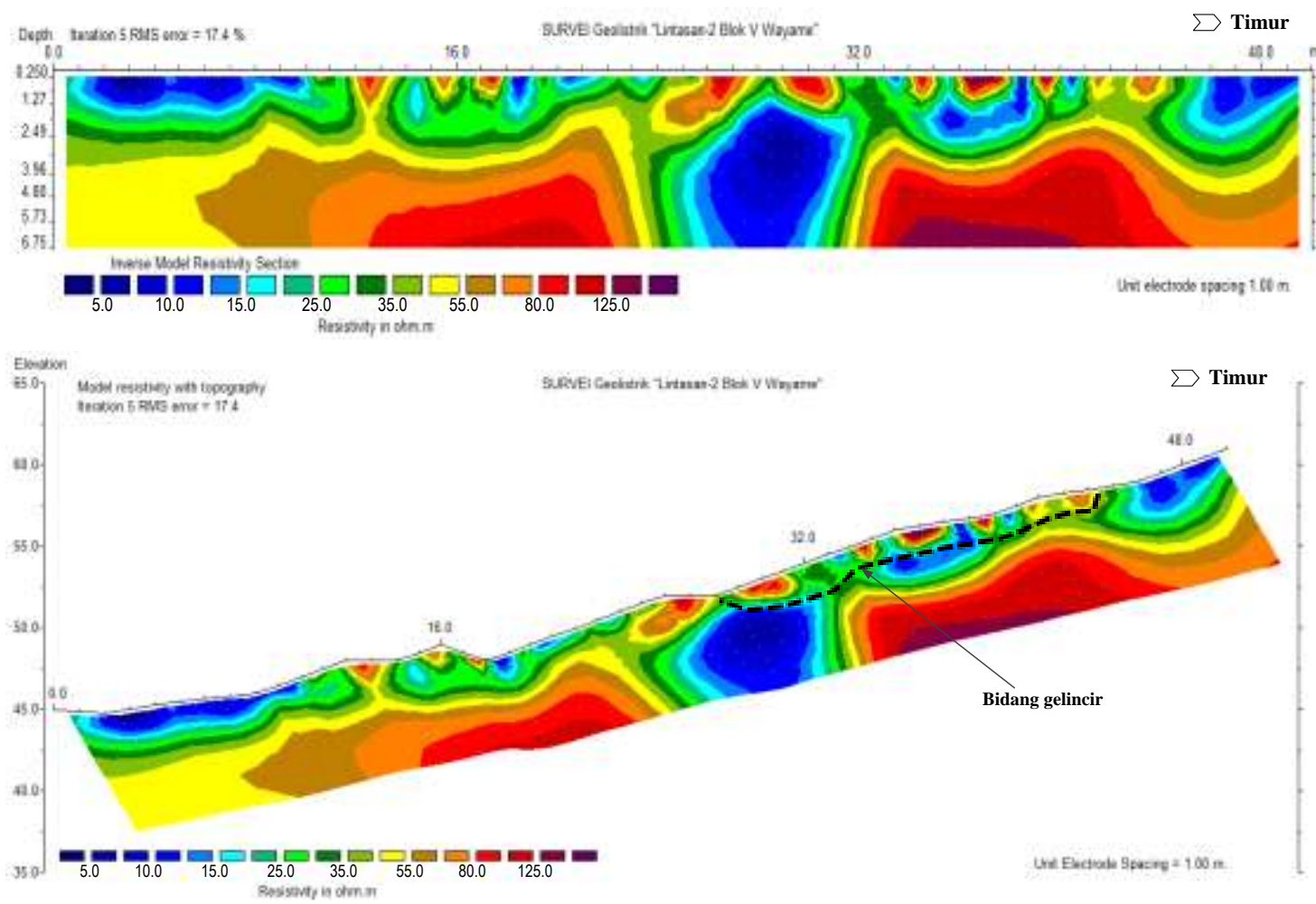

Gambar 7. Peta Penampang Resistivitas 2-d Pada Lintasan-2 
Berdasarkan hasil pengolahan data true resistivity didapatkan pola susunan lapisan batuan yang menunjukkan adanya dua lapisan bidang gelincir yaitu zona jenuh dan tak jenuh (Tabel 2). Lapisan bidang gelincir sebagai objek penelitian memiliki nilai resistivitas yang relatif rendah berhimpitan dengan lapisan overburden dan bedrock dengan nilai resistivitas tinggi.

Tabel 2. Interpretasi Litologi Berdasarkan Resistivitas Batuan Pada Lintasan-2

\begin{tabular}{|c|l|l|l|l|}
\hline $\begin{array}{c}\text { Resistivitas } \\
\text { sebenarnya } \rho,(\Omega . m)\end{array}$ & \multicolumn{1}{|c|}{ Warna } & $\begin{array}{c}\text { Zona } \\
\text { Resistivitas }\end{array}$ & Kedalaman, (m) & \multicolumn{1}{|c|}{ Interpretasi Litologi } \\
\hline$<25.0$ & \\
$25.0-55.0$ & $\square \square \square \square$ & Rendah & $0.25-2.50$ dan & Lapisan tanah, lempung, \\
$>55.0$ & $\square \square$ & Menengah & $2.50-\sim$ & lempung pasiran \\
& $\square \square \square \square \square \square \square$ & Tinggi & $0.25-2.50$ dan & Pasir, pasir lempungan \\
Tufa-lempung pasiran dan \\
batuan lempung kompak
\end{tabular}

Nilai resistivitas yang diperoleh pada Lintasan-2 relatif bervariasi dengan informasi kedalaman mencapai $7.0 \mathrm{~m}$ dari permukaan. Penskalaan penampang resistivitas diatur pada interval $2.0-200.0 \Omega$.m sehubungan dengan informasi yang dicari relatif berfokus pada kontras antara nilai resistivitas rendah, menengah dan tinggi. Kontras resitivitas pada lintasan ini hampir sama dengan Lintasan-1, dimana daerah bernilai resistivitas rendah yang dicitrakan dengan warna biru mudah hingga biru tua terakumulasi pada dua bagian terpisah yang dibatasi oleh zona dengan nilai resistivitas menengah hingga tinggi (warna hijau muda, kuning, merah hingga ungu). Pada zona resistivitas rendah berada di lapisan atas dengan kedalaman antara $0.25-2.5 \mathrm{~m}$. Interpretasi rincian dari hasil perhitungan dan pengolahan data, secara umum dari tiap datum point pada penampang resistivitas menunjukkan nilai resistivitas antara $5.0-125.0 \Omega$.m sebagai berikut:

1. Zona resistivitas rendah dengan nilai resistivitas $<25.0 \Omega$.m diduga sebagai tanah, lempung dan lempung pasiran, umumnya bersifat lepas dan lembab berwarna coklat hingga coklat-jingga. Material ini umumnya bersifat lepas/lapuk dan cukup berpori sehingga dapat meloloskan air dengan tingkat rendah.

2. Zona resistivitas menengah dengan nilai resistivitas 25.0 - 55.0 $\Omega . m$ diduga sebagai pasir, pasir lempungan berbutir halus hingga kasar, lempungan dan kerikilan. Batuan ini terdapat pada kedalaman dan ketebalan bervariasi. Material ini umumnya bersifat lepas/lapuk dan cukup berpori/berongga sehingga dapat meloloskan air dengan tingkat tinggi.

3. Zona resistivitas tinggi dengan nilai resistivitas tinggi $>55.0 \Omega$.m diduga sebagai batu lempung pasiran berbutir halus hingga sedang dan batulempung yang kompak dan keras. Batuan ini terdapat pada kedalaman dan ketebalan bervariasi. Material ini umumnya bersifat kompak. Zona batuan ini umumnya bertindak sebagai batuan dasar (bedrock) dan batuan penutup (overburden) yang dijumpai hampir di seluruh daerah survei.

Berdasarkan citra anomali resistivitas dalam Gambar 7, diduga terdapat satu bidang gelincir masingmasing panjang $\pm 16.5 \mathrm{~m}$ dari posisi $x=28.0 \mathrm{~m}$ pada kedalaman $2.5 \mathrm{~m}$ dari permukaan tanah. Anomali resistivitas sebaran longsor yang terjadi di zona ini pada arah vertikal cukup dangkal hanya mencapai kedalaman lebih dari $2.50 \mathrm{~m}$. Dari citra penampang resisitivitas (Gambar 7), menunjukkan bahwa daerah penelitian merupakan daerah yang rawan longsor. Karena terdapat kontras antara lapisan batuan dengan resistivitas rendah, menengah dan tinggi. Lapisan batuan dengan bagian resistivitas rendah berupa batuan lempung yang bersifat lepas dan lembab dan lapisan batuan dengan resistivitas menengah yang memiliki batuan lempung berbutir halus hingga kasar dan cukup berpori sera berongga sehingga dapat meloloskan air karena pada lapisan ini jenuh air sehingga mempunyai beban yang lebih berat. Sedangkan lapisan batuan dengan resistivitas tinggi adalah batuan dasar (bedrock) tak lapuk, sehingga apabila ada air yang masuk pada daerah ini, air tersebut akan tertahan di lapisan ini, sehingga lapisan tersebut akan menjadi licin dan mudah tergelincir. Akibat licinnya lapisan tersebut, maka sangat memungkinkan munculnya longsor susulan.

Hasil pemodelan resisitivitas yang diperoleh pada Gambar 7, terdapat beberapa kesalahan (error) yaitu kesalahan pemotongan eksekusi nilai resitivitas dan kesalahan topografi. Kesahalah ini ditunjukkan dari hasil running program (Gambar 8) dengan kesalahan pemotongan (cutoff error) dari $150 \%$ menghasilkan batas kesalahan maksimum $87.3 \%$. Sedangkan kesalahan akar rataan kuadrat (Root Mean Square) selama 
proses iterasi untuk mendapatkan resistivitas sebenarnya adalah sebesar $17.4 \%$. Kesalahan ini masih dalam taraf yang dapat diterima sebagai hasil proses inversi yang presisi sesuai dengan kondisi lapangan.

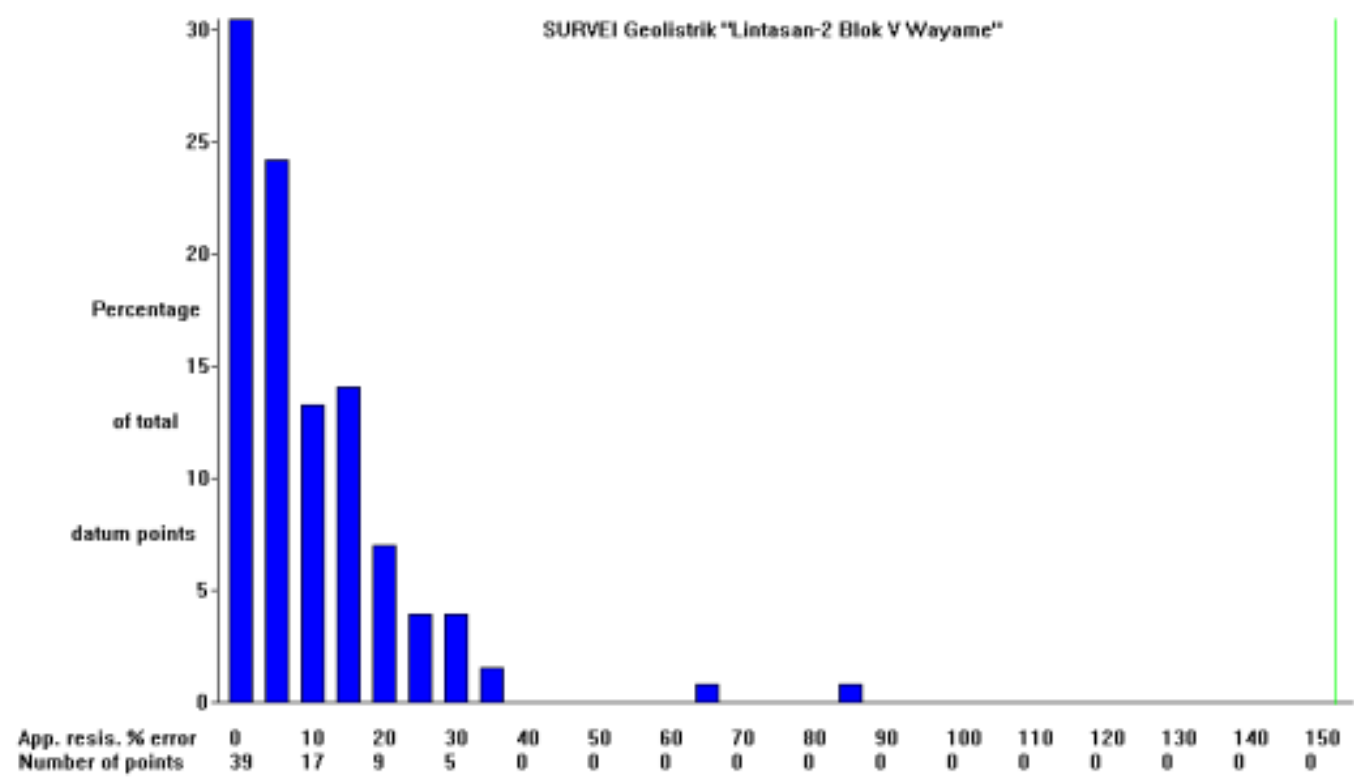

Gambar 8. Statistik Kesalahan Pengolahan Data Pada Lintasan-2

\subsection{Konektivitas Interpretasi Resistivitas Batuan Pada Daerah Penelitian}

Secara umum gerakan tanah yang terjadi di daerah penelitian merupakan gerakan tanah jenis longsor debris dengan bidang gelincir berbentuk slide rotasi. Material longsor berupa tanah lempung pasiran (silty clay) berbutir halus dan kasar. Material lempung pasiran sangat mudah meresapkan air hujan ke dalam lereng, sedangkan air yang meresap pada lapisan tanah tidak dapat meresap pada lapisan batuan dasar yang kedap air (impermeable), akibat adanya air hujan tertahan dan terakumulasi dalam tanah di atas batuan dasar dan cenderung berusaha mengalir ke dalam dan menekan lereng menambah beban massa tanah di atasnya sehingga berpotensi menjadi media gelincir yang licin (hasil pemodelan geolistrik resistivitas).

Hasil pemodelan dengan menampilkan konektivitas resitivitas 2-D (Gambar 9) menunjukkan bahwa daerah penelitian merupakan daerah yang rawan longsor karena berada di jalur patahan seperti seperti hasil penelitian yang disampaikan oleh [9]. Daerah yang terindikasi sebagai daerah rawan longsor dapat memunculkan longsor susulan. Hal ini teridentifikasi adanya bidang gelincir pada kedua lintasan ukur (Gambar 9). Pada Lintasan-1 diduga mempunyai dua bidang gelincir yang merupakan bidang rawan longsor terletak pada zona resistivitas menengah dengan jenis pasir atau pasir lempungan yang menindih zona resistivitas tinggi yang berupa batul empung keras (bedrock) [11]. Alterasi anomali ini memungkinkan potensi sebaran longsor tetap pada lokasi semula apabila terjadi gangguan-gangguan pada lereng tersebut dan berpeluang bergeser ke arah Timur Laut dan juga berpeluang menyebar ke arah Barat Laut dan Timur dengan prediksi kekuatan longsor berkurang dari sebelumnya. Sedangkan pada arah horizontal sebaran longsor mengikuti arah kemiringan potensi longsor searah dengan bidang gelincir yaitu mengarah ke Barat Daya menuju pemukiman penduduk. Untuk Lintasan-2, diduga mempunyai satu bidang gelincir, merupakan bidang rawan longsor terletak pada zona resistivitas menengah dengan jenis pasir atau pasir lempungan yang menindih zona resistivitas tinggi yang berupa batu lempung keras. Alterasi anomali resistivitas memungkinkan potensi sebaran longsor tetap pada lokasi semula apabila terjadi gangguangangguan pada lereng tersebut dan berpeluang bergeser ke arah Timur serta berpeluang menyebar ke arah Timur Laut dan Tenggara dengan prediksi kekuatan pergerakan material longsor berkurang dari sebelumnya. Sedangkan pada arah horizontal sebaran longsor mengikuti arah kemiringan potensi longsor searah dengan bidang gelincir yaitu mengarah ke Barat Daya menuju pemukiman penduduk.

Dengan diduga adanya bidang gelincir pada daerah penelitian, hal ini menunjukkan bahwa jika bidang gelincir menerima beban secara terus-menerus dari air hujan dan adanya deformasi batuan maka gaya kohesi dan gesekan menjadi berkurang dari bagian bawah dalam lereng menuju ke permukaan lereng atau sampai pada bidang licin (tanah lempung atau kohesif), akibatnya lereng menjadi tidak stabil [1, 14]. Adanya ketidakstabilan lereng ini mengakibatkan bahwa material lempung pasiran yang ada di atas bidang 
licin akan meluncur mengikuti lereng dengan energi kinetik yang besar [15], karena kekuatan atau gaya pendorong melebihi dari gaya penahan lereng.

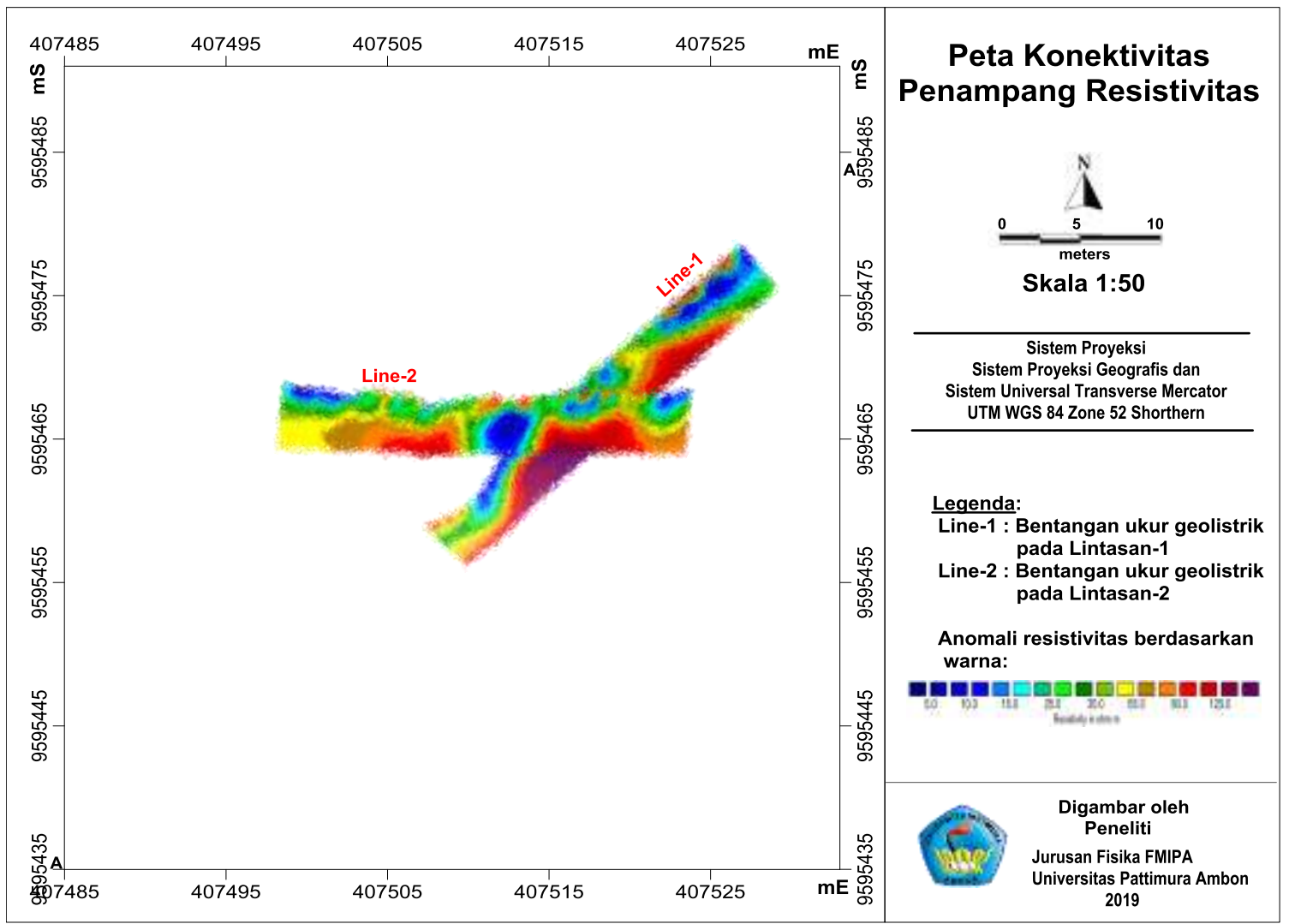

Gambar 9. Peta Konektivitas Penampang Resistivitas Batuan Pada Lintasan-1 dan Lintasan-2

\section{KESIMPULAN}

Berdasarkan hasil interpretasi dan pembahasan, maka dapat disimpulkan bahwa:

1. Telah dilakukan survei geolistrik resistivitas menggunakan konfigurasi Wenner-Schlumberger pada daerah bekas longsor Blok V Wayame Ambon, diduga terdapat tiga struktur lapisan batuan bawah permukaan bumi, yaitu lapisan batuan dengan zona resistivitas rendah $(<25.0 \Omega$.m) sebagai tanah, lempung dan lempung pasiran. Lapisan batuan dengan zona resistivitas menengah $(25.0-55.0$ $\Omega . m$ ) berupa pasir dan lempungan pasiran, dan lapisan batuan dengan zona resistivitas tinggi (> 55.0 $\Omega . m$ ) berupa batuan lempung pasiran dan batuan lempung yang kompak dan keras.

2. Hasil pemodelan resistivitas batuan teridentifikasi adanya zona bidang gelincir pada kedua lintasan pengukuran, dimana pada Lintasan-1 diinterpretasi memiliki dua bidang gelincir ditemukan pada kedalaman $2.0 \mathrm{~m}$ terletak pada jarak $6.0 \mathrm{~m}$ dan $38.0 \mathrm{~m}$ dari posisi awal, sedangkan pada Lintasan-2 diinterpretasi mempunyai satu bidang gelincir ditemukan pada kedalaman $2.5 \mathrm{~m}$ terletak pada jarak $28.0 \mathrm{~m}$ dari posisi awal. Zona bidang gelincir yang merupakan bidang rawan longsor terletak pada zona resistivitas menengah (25.0-55.0 $\Omega . \mathrm{m})$ yang menindih zona resistivitas tinggi (> 55.0 $\Omega . \mathrm{m}$ ). Zona yang rawan longsor dapat berpotensi munculnya longsor susulan dengan memungkinkan potensi sebaran longsor tetap pada lokasi semula apabila terjadi gangguan-gangguan pada lereng dan berpeluang bergeser ke arah atas lereng dan juga berpeluang menyebar ke arah sebelah kiri dan kanan pada bagian atas lereng.

3. Untuk menghidari munculnya longsor susulan diperlukan prevensi dan mitigasi berupa penerapan model bioengineering dan geoforestry yang dilengkapi dengan model sistem tol air. 


\section{UCAPAN TERIMA KASIH}

Penulis mengucapkan terima kasih kepada Laboratorium Geofisika dan Geosains Jurusan Fisika FMIPA Unpatti yang telah menyiapkan peralatan untuk akuisisi geolistrik. Ucapan terima kasih disampaikan pula kepada redaksi Jurnal Barekeng serta rekan-rekan yang telah banyak membantu sehingga penelitian ini dapat diselesaikan.

\section{DAFTAR PUSTAKA}

[1] D.H. Cornforth, "Landslides in practice: Investigations, analysis, and remedial/preventive options in soils", $1^{\text {st }}$ edition, John Wiley \& Sons, Inc., USA, 2004.

[2] D.J. Varnes, "Slope movements types and processes in landslide: Analysis and control", Nation Academy of Sciences, Washington, DC, 176, 11 - 33, 1978.

[3] D. Santoso, "Pengantar Teknik Geofisika", Penerbit ITB, Bandung, 111, 2002.

[4] M.S. Sapulete, Sismanto dan M. Souisa, "Mapping of Lateritic Nickel Deposit Using Resistivity Method at Gunung Tinggi Talaga Piru, Western Seram Regency, Mollucas Province", Proceeding Earth Science International Seminar, Yogyakarta, 132-138, 29th November 2012.

[5] M. Souisa, "Model Fisika Gerakan Tanah Penutup Lereng Curam di Pulau Ambon", Disertasi Doktor, Institut Teknologi Bandung, 2018.

[6] M. Souisa, L. Hendrajaya dan G. Handayani, "Investigasi Awal Mekanisme Tanah Longsor di Pulau Ambon, Provinsi Maluku", Prosiding Seminar Nasional Basic Science VI, Fakultas Matematika dan Ilmu Pengetahuan Alam, Universitas Pattimura, Ambon, Vol.1, 23-31, 2014.

[7] M. Souisa, L. Hendrajaya and G. Handayani, "Landslide Hazard and Risk Assessment for Ambon City Using Landslide Inventory and Geographic Information System", Journal of Physics: Conference Series, 739, 1-11, 2016.

[8] M. Souisa, L. Hendrajaya dan G. Handayani, "Pencitraan Resistivitas Bidang Longsor di Perbukitan Booi dan Erie Kota Ambon Menggunakan Konfigurasi Wenner-Schlumberger", Spektra: Jurnal Fisika dan Aplikasinya, UNJ, Jakarta, Vol.16 No.2, 1-5, 2015.

[9] M. Souisa, L. Hendrajaya and G. Handayani, "Landslide Dynamics and Determination Critical Condition Using of Resistivity Method in Desa Negeri Lima Ambon", Indonesian Journal of Physics, Vol.26, No.1, 1-4, 2016

[10] M. Souisa, L. Hendrajaya and G. Handayani, "Determination of Landslide Slip Surface Using Geoelectrical Resistivity Method at Ambon City Moluccas Indonesia", Internasional Journal, IJETAE, Vol.5, Issue 7, 42-47, 2015.

[11] M. Souisa, L. Hendrajaya dan G. Handayani, "Prediksi Volume Potensi Longsoran Berdasarkan Inversi Resistivitas (Studi Kasus di Amahusu dan Erie Ambon), Prosiding Seminar Nasional Fisika, Vol.5, 17-22, 2016.

[12] M. Souisa, L. Hendrajaya and G. Handayani, "Study on Estimates of Travel Distance, Velocity and Potential Volume of Amahusu Sliding Plane using Energy Conservation Approach in Conjunction with Geoelectric Survey", Journal of Mathematical and Fundamental Sciences, Vol. 50, No. 2, 166-181, 2018.

[13] M.W.Telford, L.P. Geldart, R.E. Sherrif dan D.A. Keys, Applied Geophysics, Cambridge University Press, Cambridge New York, 523-524, 2004.

[14] NGA (Northwest Geophysical Associate), "D.C. Resistivity Retrieved", from http://www.nga.com/Flyers_PDF/ NGA_DC_Resistivity.pdf, August 23rd, 2010.

[15] S. Tjokrosapoetro, E. Rusmana, dan Suharsono, "Geologi Lembar Ambon, Maluku (Geological Map of the Ambon Sheet, Maluku) Lembar (Sheet) 2612-2613, Skala (Scale) 1:250.000", Direktorat Jenderal Geologi dan Sumberdaya Mineral, Pusat Penelitian dan Pengembangan Geologi, Republik Indonesia, 3-11, 1994 